\title{
Ancestral Caddo Ceramic Vessel Sherds from Sites in the White Oak Creek Basin, Hopkins County, Texas
}

Timothy K. Perttula

Follow this and additional works at: https://scholarworks.sfasu.edu/ita

Part of the American Material Culture Commons, Archaeological Anthropology Commons, Environmental Studies Commons, Other American Studies Commons, Other Arts and Humanities Commons, Other History of Art, Architecture, and Archaeology Commons, and the United States History Commons

Tell us how this article helped you.

This Article is brought to you for free and open access by the Center for Regional Heritage Research at SFA ScholarWorks. It has been accepted for inclusion in Index of Texas Archaeology: Open Access Gray Literature from the Lone Star State by an authorized editor of SFA ScholarWorks. For more information, please contact cdsscholarworks@sfasu.edu. 


\section{Ancestral Caddo Ceramic Vessel Sherds from Sites in the White Oak Creek Basin, Hopkins County, Texas}

\section{Creative Commons License}

\section{(c) (1) \&}

This work is licensed under a Creative Commons Attribution-NonCommercial 4.0 International License 


\title{
Ancestral Caddo Ceramic Vessel Sherds from Sites in the White Oak Creek Basin, Hopkins County, Texas
}

\author{
Timothy K. Perttula
}

\section{Introduction}

The ancestral Caddo ceramic vessel sherd assemblages discussed in this article are from five sites in the White Oak Creek basin in the Blackland Prairie of East Texas (Figure 1). They are the E. B. Minter Farm (41HP2), R. H. Taylor Farm (41HP4), Hilman Hathcoat (41HP9), Avery Rasurer (41HP10), and Tom Cannon Farm (41HP11) sites. They were investigated by archaeologists from The University of Texas in 1931 or 1934 who were in search of whole Caddo vessels and burial features, and the collections obtained from the sites (including donated or purchased collections) are held by the Texas Archeological Research Laboratory at The University of Texas at Austin (TARL). The collections include ceramic vessel sherds from each of the sites, elbow pipes from two of the sites, and a few vessels from the E. B. Minter and R. H. Taylor Farm sites.

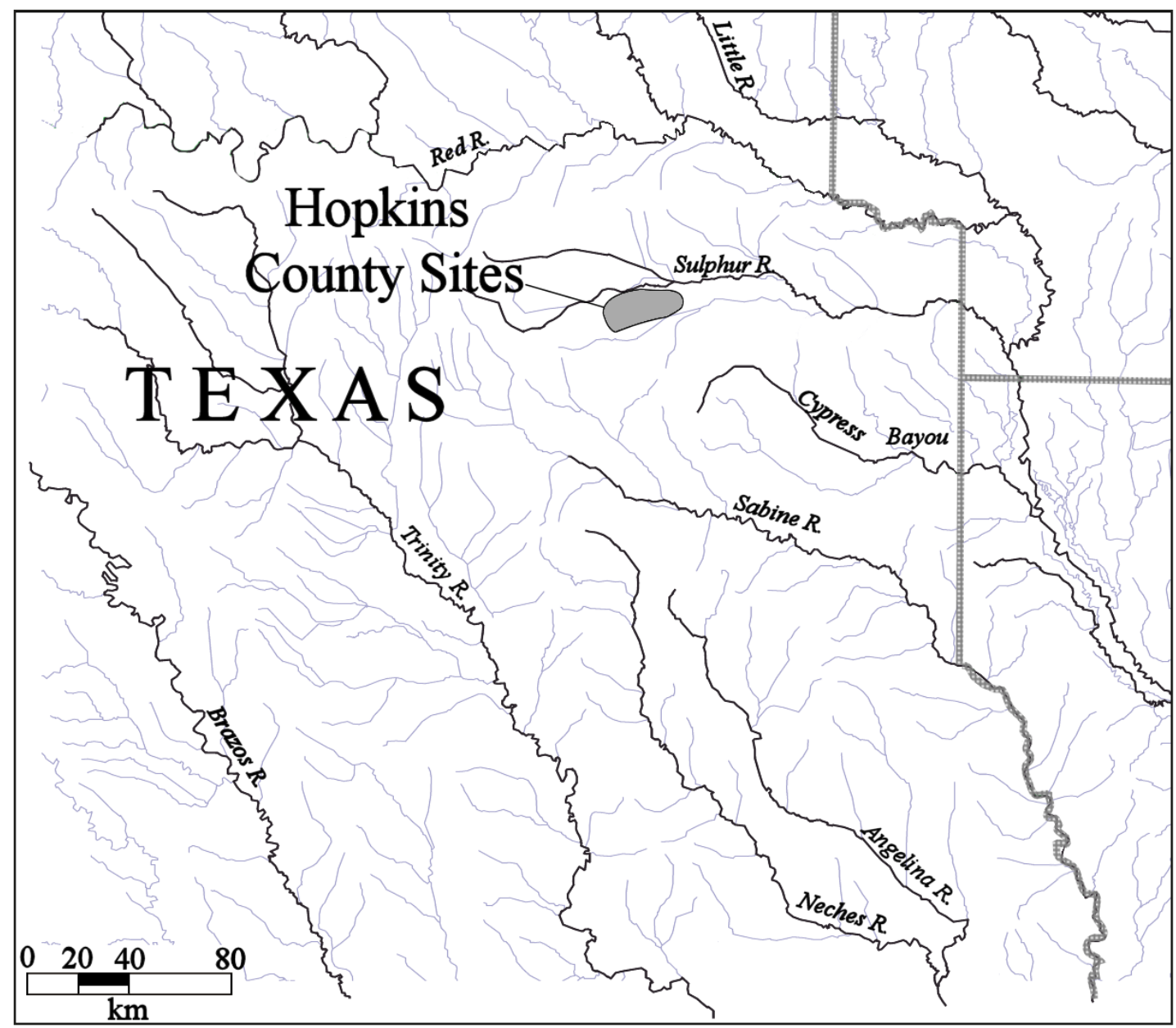

Figure 1. Location of Ancestral Caddo sites in the White Oak Creek Basin in East Texas. 


\section{E. B. Minter Farm (41HP2)}

The University of Texas (UT) conducted excavations at the E. B. Minter site in May 1931 (Jackson 1931). Initially, a $60 \times 35 \mathrm{ft}$. area was excavated on a sandy knoll at that time based on a report that ceramic vessels and ceramic pipes had been found there in years past, but no features were found. There were midden deposits there that ranged from ca. $20-51 \mathrm{~cm}$ bs. A second area by a county road, ca. 100 $\mathrm{m}$ from the first excavation area, exposed Burial 1 at a depth of ca. $77 \mathrm{~cm}$ bs; Jackson (1931) noted that ceramic vessels had been found in this area months earlier by road grading work along the road. Burial 1 was apparently laid out in an east-west orientation based on the position of the ceramic vessels; no human remains were preserved in the burial feature.

Burial 1 was accompanied by four crushed grog-tempered ceramic vessels (Perttula and Walters 2016:64-67 and Figures 2 and 3), one arrow point, and a broken celt. These included two Sanders Engraved carinated bowls with diagonal opposed engraved lines on the rim panels, a plain bottle, and a plain bowl. The E. B. Minter Farm (41HP2) vessels are from a Middle Caddo period (ca. A.D. 12001400) burial associated with Sanders phase occupations in the upper Red, Sulphur, Big Cypress, and Sabine River basins.

\section{Ceramic Vessel Sherds}

A total of 112 ceramic vessel sherds are in the TARL collections from the E. B. Minter Farm (Table 1); the sherds likely are from the midden area, not the area of the Middle Caddo period ceramic vessels. The ceramic sherds are from grog-tempered vessels; 2.7 percent of the sherds also have crushed pieces of hematite added to the paste in addition to the grog.

Table 1. Ceramic wares and temper use in the E. B. Minter Farm (41HP2) sherd assemblage.

\begin{tabular}{lccc}
\hline & \multicolumn{2}{c}{ Temper Categories } & \\
Ware & Grog & Grog-Hematite & N \\
\hline Plain & 72 & 2 & 74 \\
Utility & 16 & - & 16 \\
Fine & 21 & 1 & 22 \\
\hline Totals & 109 & 3 & 112 \\
\hline
\end{tabular}

The decorated sherds in the assemblage are from both utility ware (42 percent) and fine ware (58 percent) vessels, all but one of which are from vessels tempered solely with grog. Only 25 percent of the rim sherds are from utility wares, while the remainder are from fine ware engraved vessels, typically carinated bowls (Table 2). 
Table 2. Decorative methods and decorative elements in the E. B. Minter Farm (41HP2) sherd assemblage.

Decorative method and decorative element

Rim

Body

$\mathrm{N}$

\section{Utility ware}

Appliqued

straight appliqued fillet

Brushed

parallel brushed marks

Brushed-Incised

parallel brushed-incised marks and lines

Incised

diagonal opposed incised lines

horizontal incised lines

parallel incised lines

straight incised line

Neck Banded

horizontal neck bands

$\begin{array}{lll}- & 2 & 2 \\ 1 & - & 1 \\ - & 5 & 5 \\ - & 1 & 1\end{array}$

\section{Punctated}

fingernail punctated row

tool punctated row

\section{Fine ware}

\section{Engraved}

circle el. and bracket el.

curvilinear engraved lines

diagonal opposed engraved lines

hatched diagonal engraved column

horizontal engraved line under lip

horizontal engraved lines, widely-spaced

horizontal engraved lines-excised brackets

horizontal-diagonal engraved lines

horizontal-vertical engraved lines

parallel engraved lines

scroll lines

scroll fill el.

straight engraved line

$\begin{array}{lll}- & 1 & 1 \\ - & 1 & 1 \\ 1 & 1 & 2 \\ - & 1 & 1 \\ 1 & - & 1 \\ - & 1 & 1 \\ - & 1 & 1 \\ 1 & - & 1 \\ 1 & 2 & 3 \\ - & 2 & 2 \\ 1 & - & 1 \\ 1 & 1 & 2 \\ - & 2 & 2\end{array}$

\section{Red-slipped}

exterior red-slipped interior red-slipped

int./ext. red-slipped

\begin{tabular}{lll}
- & 1 & 1 \\
- & 1 & 1 \\
- & 1 & 1 \\
\hline 8 & 30 & 38
\end{tabular}

Totals 
About 19 percent of the utility ware sherds are from brushed and brushed-incised vessels (see Table 2), probably from Bullard Brushed jars (see Suhm and Jelks 1962:Plate 11). One body sherd (6.3 percent of the utility wares) has a single straight appliqued fillet, and one rim sherd is from a La Rue Neck Banded jar (see Suhm and Jelks 1962:Plate 47). Two other sherds (12.5 percent of the utility wares) have a row of either fingernail or tool punctations, likely restricted to the vessel rim, and the remainder of the utility wares (56 percent) have incised decorative elements. These include parallel and straight incised lines, diagonal opposed incised lines (from either Canton Incised or Maydelle Incised vessels, see Suhm and Jelks 1962:Plates 12 and 52)), and a rim with horizontal incised lines (see Table 2).

The fine ware sherds are from either engraved or red-slipped vessels (see Table 2). Two sherds with diagonal opposed engraved lines are from Middle Caddo period Sanders Engraved carinated bowls (see Perttula et al. 2016); one of these sherds has a red pigment rubbed in the engraved lines. Other engraved sherds are from Late Caddo Titus phase Ripley Engraved vessels with scroll elements (Figure 2a-b; see Suhm and Jelks 1962:Plate 64). A bottle sherd has a circle element with a connecting bracket element (Figure 2c), and may be from a Ripley Engraved bottle (Suhm and Jelks 1962:Plate 65).
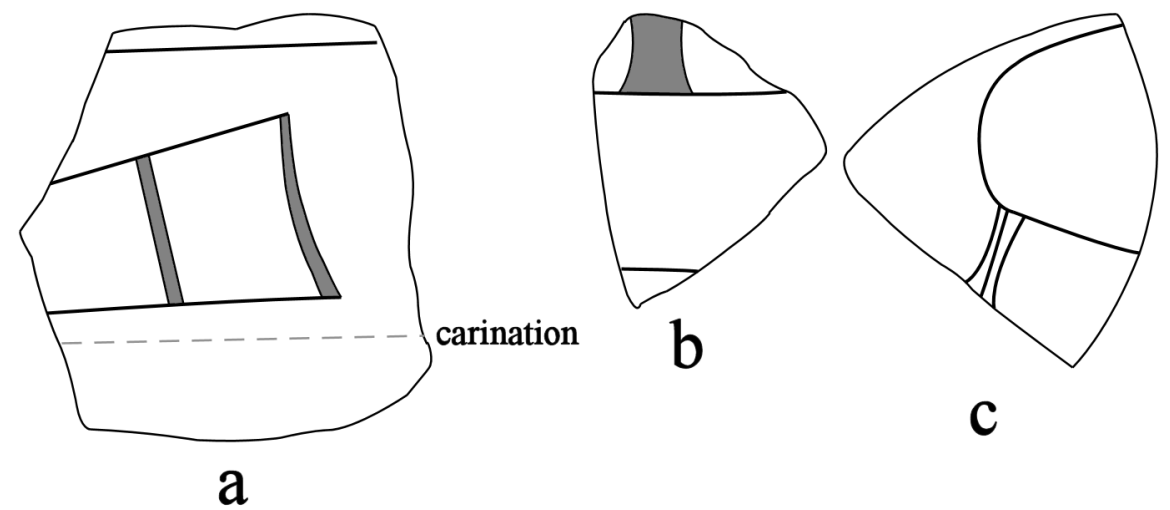

Figure 2. Decorative elements on Ripley Engraved vessel sherds from the E. B. Minter Farm site (41HP2) ceramic assemblage.

The red-slipped sherds (13.6 percent of the fine wares) have a hematite-rich red slip on either interior, exterior, or interior and exterior vessel surfaces. These sherds may be from Sanders Slipped vessels, dating to the Middle Caddo period (see Perttula et al. 2016), or are from the non-engraved portions of later vessels such as Ripley Engraved, which is often red-slipped on both vessel surfaces and have engraved motifs only on the rim panels.

\section{Ceramic Pipe Sherd}

Also recovered during the excavations at the E. B. Minter Farm is a single grog-tempered undecorated elbow pipe bowl sherd of Late Caddo period age. The pipe sherd is $7.9 \mathrm{~mm}$ in thickness.

Overall, the ceramic vessels and ceramic vessel sherds from the E. B. Minter Farm (41HP2) represent two different ancestral Caddo occupations. The first dates to the Middle Caddo period (ca. A.D. 1200-1400) and is affiliated with Sanders phase occupations in the upper Red, Sulphur, and Sabine river basins, while the second dates to the Late Caddo period, dating from ca. A.D. 1400-1680, and the Titus phase. Titus phase Caddo sites are well-distributed across the Big Cypress, Sabine and mid-Sulphur River basins in East Texas (see Perttula 2012:13-1a-b). 


\section{R. H. Taylor Farm (41HP4)}

Some time prior to 1934 a decorated elbow pipe (Figure 3) and an engraved and carinated bottle (Figure 4) of the Taylor Engraved type had been plowed up on the R. H. Taylor Farm. UT archaeologists investigated the site in July 1934 (Jackson 1934) and uncovered sherds from two broken ceramic vessels and a large assemblage of plain and decorated vessel sherds.

The TARL collections have 237 sherds from plain ware, utility ware, and fine ware sherds (Table 3 ). Although there is no provenience information available concerning the sherd collection from the R. H. Taylor Farm, the majority of the rim sherds are likely from the two broken vessels mentioned by Jackson (1934), which are a distinctive variety of Sanders Engraved (see below).

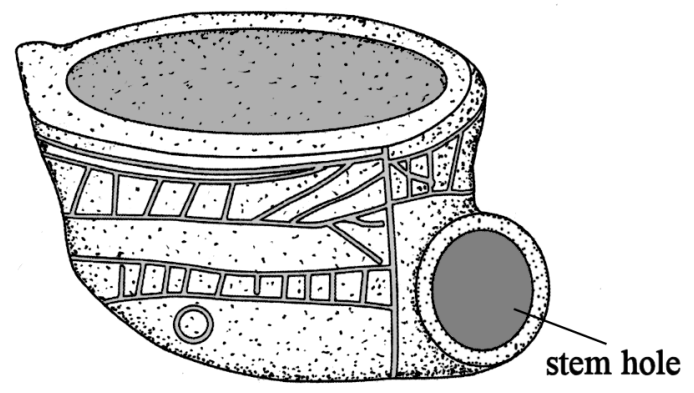

Figure 3. Decorated elbow pipe plowed up at the R. H. Taylor Farm site (41HP4) (after Jackson 1934).

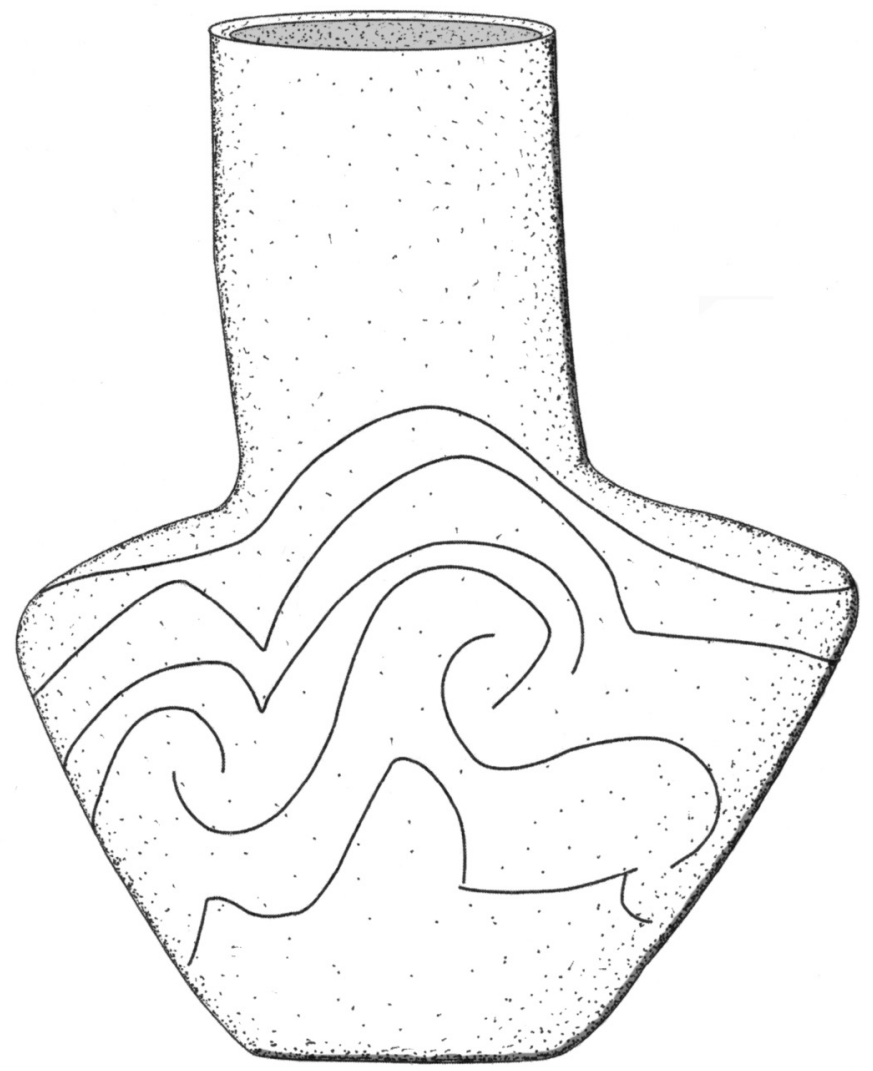

Figure 4. Engraved bottle plowed up at the R. H. Taylor Farm site (41HP4) (after Jackson 1934). 
Table 3. Ceramic wares and temper use in the R. H. Taylor Farm (41HP4) sherd assemblage.

\begin{tabular}{lllll}
\hline Ware & Grog & $\begin{array}{c}\text { Temper Categories } \\
\text { Grog-Bone }\end{array}$ & Bone & N \\
\hline Plain & 152 & 20 & 1 & 173 \\
Utility & 7 & - & - & 7 \\
Fine & 51 & 6 & - & 57 \\
\hline Totals & 210 & 26 & 1 & 237 \\
\hline
\end{tabular}

Almost 90 percent of the sherds are from grog-tempered vessels (see Table 3). Another 11 percent are from vessels tempered with both grog and bone, and 0.4 percent of the sherds are from a bone-tempered vessel. Notably, 89 percent of the decorated sherds $(n=64)$ from the $R$. H. Taylor Farm site are from fine wares.

The utility ware sherds in the assemblage from the R. H. Taylor Farm site include two rim sherds and five body sherds. The rim sherds have notched lips, while the body sherds have incised-punctated, tool punctated, and trailed lines (Table 4). The rim sherds with notched lips may be related to the Sanders Engraved rim sherds with notched lips found at the site (see below), although the former sherds are otherwise plain.

Table 4. Decorative methods and decorative elements in the R. H. Taylor Farm (41HP4) sherd assemblage.

\begin{tabular}{llll}
\hline Decorative method and decorative element & Rim & Body & $\mathrm{N}$ \\
\hline
\end{tabular}

\section{Utility ware}

Incised-Punctated

straight incised line-adjacent fingernail punctation

$\begin{array}{lll}- & 1 & 1 \\ 2 & - & 2 \\ - & 3 & 3 \\ - & 1 & 1\end{array}$

Notched

notched lip

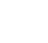

Fine ware

\section{Engraved}

diagonal engraved lines

diagonal opposed engraved lines

engraved triangle el. with diagonal hatched lines

$1+$ horizontal engraved line

horizontal zone with vertical hatched lines

horizontal-diagonal engraved lines

parallel engraved lines

\begin{tabular}{lll}
1 & 10 & 11 \\
21 & 8 & 29 \\
- & 6 & 6 \\
- & 1 & 1 \\
1 & - & 1 \\
- & 2 & 2 \\
- & 1 & 1 \\
& & \\
- & 5 & 5 \\
- & 1 & 1 \\
\hline 25 & 39 & 64
\end{tabular}

Red-slipped

exterior red-slipped

int./ext. red-slipped

Totals 
The fine ware sherds are from both engraved (89.5 percent of the fine wares) and red-slipped (10.5 percent) vessels (see Table 4); the red-slipped sherds are from Sanders Slipped vessels (Perttula et al. 2016). The majority of the fine ware sherds are from Sanders Engraved, var. Taylor Farm carinated bowls (from at least two vessels) with diagonal opposed engraved lines and distinctive notched lips (Figure 5ac). Other Sanders Engraved vessel sherds have opposed engraved triangles filled with diagonal engraved lines (Figure 6b-c) along with open undecorated triangular areas. A rim sherd from another vessel has a narrow engraved horizontal zone filled with vertical hatched lines (Figure 6a).

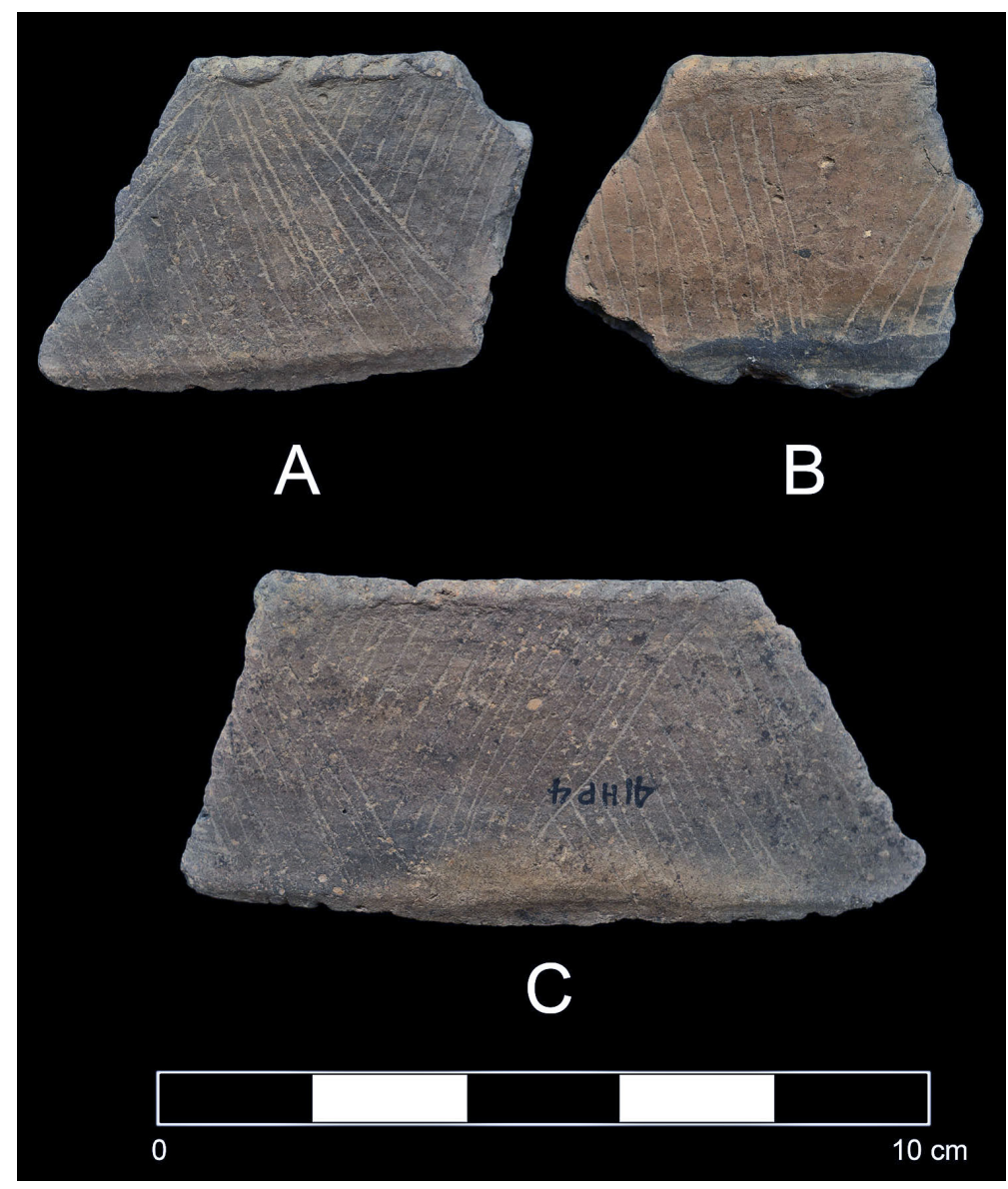

Figure 5. Sanders Engraved, var. Taylor Farm rim sherds from the R. H. Taylor Farm site (41HP4).

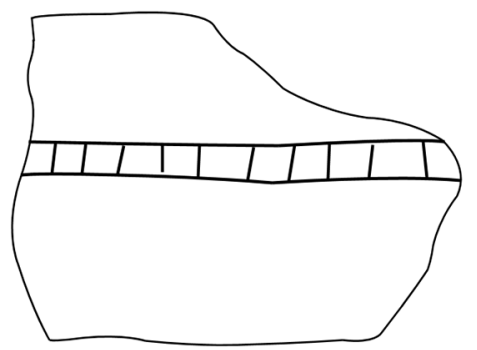

a

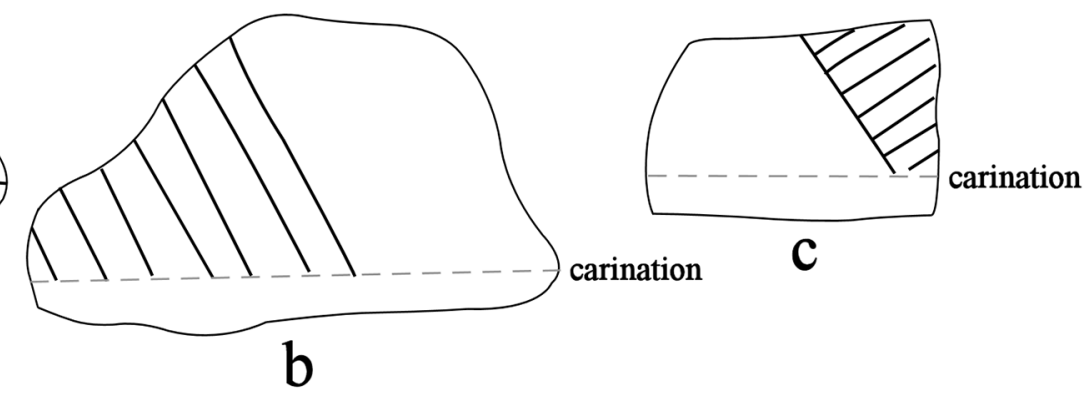

Figure 6. Engraved decorative elements from fine ware sherds from the R. H. Taylor Farm site (41HP4): a, vertical hatched zone; b-c, Sanders Engraved. 


\section{Hilman Hathcoat (41HP9)}

The Hilman Hathcoat site is on Cross Timber Creek in the White Oak Creek basin. UT archaeologists heard that in 1933 a burial was excavated at the site by a J. A. Bearden; a ceramic pipe of unknown form was reported to have been found in association with the burial feature. In June 1934, a surface collection of materials from the site was donated to UT, and it was noted by UT archaeologists at the time that the site had a midden deposit ca. $15 \mathrm{~m}$ in diameter and $60-90 \mathrm{~cm}$ in depth. UT archaeologists conducted no test excavations at the site.

The sherds from ceramic vessels in the donated collection from the site are almost exclusively from vessels tempered with grog (95.7 percent), including sherds with both grog and bone temper (Table 5). The remainder of the sherds are tempered with bone ( 2.1 percent) or bone and hematite ( 2.1 percent). Four of the plain grog-tempered base sherds are from very thick vessels (13.0-19.5 mm), and may be from Williams Plain flat-based vessels. The eight decorated sherds in the Hilman Hathcoat ceramic sherd assemblage are from utility ware ( 75 percent) and fine ware ( 25 percent) vessels.

Table 5. Ceramic wares and temper use in the Hilman Hathcoat site (41HP9) sherd assemblage.

\begin{tabular}{llllll}
\hline & \multicolumn{5}{c}{ Temper Categories } \\
Ware & Grog & Grog-Bone & Bone & Bone-Hematite & N \\
\hline Plain & 31 & 6 & 1 & 1 & 39 \\
Utility & 5 & 1 & - & - & 6 \\
Fine & 2 & - & - & - & 2 \\
\hline Totals & 38 & 7 & 1 & 1 & 47 \\
\hline
\end{tabular}

Half of the utility ware sherds have incised decorative elements (Table 6), and are likely from Canton Incised jars. Two other utility ware sherds have rows of tool punctations, and the last utility ware sherd from the site is from a jar that has a straight appliqued ridge.

Table 6. Decorative methods and decorative elements in the Hilman Hathcoat site (41HP9) sherd assemblage.

Decorative method and decorative element

Rim

Body

$\mathrm{N}$

Utility ware

Appliqued

straight appliqued ridge

Incised

cross-hatched incised lines diagonal opposed incised lines parallel incised lines

Punctated

tool punctated rows

$\begin{array}{lll}- & 1 & 1 \\ - & 1 & 1 \\ - & 1 & 1 \\ - & 1 & 1\end{array}$


Table 6. Decorative methods and decorative elements in the Hilman Hathcoat site (41HP9) sherd assemblage, cont.

\begin{tabular}{llcc}
\hline Decorative method and decorative element & Rim & Body & N \\
\hline$\underline{\text { Fine ware }}$ & & & \\
Engraved & & & 1 \\
$1+$ horizontal engraved lines & 1 & - & 1 \\
$\begin{array}{l}\text { Red-slipped } \\
\text { exterior red-slipped }\end{array}$ & 1 & - & 8 \\
\hline Totals & 3 & 5 & 5 \\
\hline
\end{tabular}

Both of the fine ware sherds from the Hilman Hathcoat site are grog-tempered rims (see Table 6).

One rim has at least one horizontal engraved line, while the other is from a Sanders Slipped vessel with a red-slipped exterior surface.

In summary, the few ceramic vessel sherds from the Hilman Hathcoat site (41HP9) suggest that the site was occupied by ancestral Caddo peoples between ca. A.D. 1200-1400, as well as perhaps earlier (ca. A.D. 850-1200) because of the thick-walled base sherds that may be from Williams Plain vessels. The possible Middle Caddo ceramic vessel sherds include examples of Canton Incised and Sanders Slipped, both common Middle Caddo period ceramic types in the Sanders phase (see Perttula et al. 2016).

\section{Avery Rasurer (41HP10)}

The TARL collections from the Avery Rasurer site are from a surface collection obtained by UT archaeologist A. M. Woolsey in June 1934. The ceramic sherds are from plain, utility, and fine ware vessels tempered with grog ( 87.5 percent) and grog-bone (12.5 percent) (Table 7). The 10 decorated sherds are divided into utility ware (80 percent) and fine ware (20 percent).

Table 7. Ceramic wares and temper use in the Avery Rasurer site (41HP10) sherd assemblage.

\begin{tabular}{llll}
\hline & \multicolumn{2}{c}{ Temper Categories } & N \\
Ware & Grog & Grog-Bone & 22 \\
\hline Plain & 18 & 4 & 8 \\
Utility & 8 & - & 2 \\
Fine & 2 & - & 32 \\
\hline Totals & 28 & 4 & 32 \\
\hline
\end{tabular}

Half of the decorated sherds in the small collection from the Avery Rasurer site are from Harleton Appliqued jars (see Suhm and Jelks 1962:Plate 33), a Late Caddo period, Titus phase ceramic type. These sherds have portions of appliqued ridge chevron elements (Table 8 and Figure 7a-b). Other decorated utility wares in the assemblage include a Maydelle Incised rim with cross-hatched lines, and two body sherds with rows of tool punctations. 
Table 8. Decorative methods and decorative elements in the Avery Rasurer site (41HP10) sherd assemblage.

\begin{tabular}{llll}
\hline Decorative method and decorative element & Rim & Body & $N$ \\
\hline
\end{tabular}

\section{Utility ware}

\section{Appliqued}

straight appliqued ridge

vertical appliqued ridges

vertical-curvilinear appliqued ridges

\section{Incised}

cross-hatched incised lines

$\begin{array}{lll}- & 3 & 3 \\ - & 1 & 1 \\ - & 1 & 1\end{array}$

\section{Punctated}

tool punctated rows

1

Fine Ware

Red-slipped

int./ext. red-slipped

$\begin{array}{ll}- & 2\end{array}$

2

Totals

1

9

10

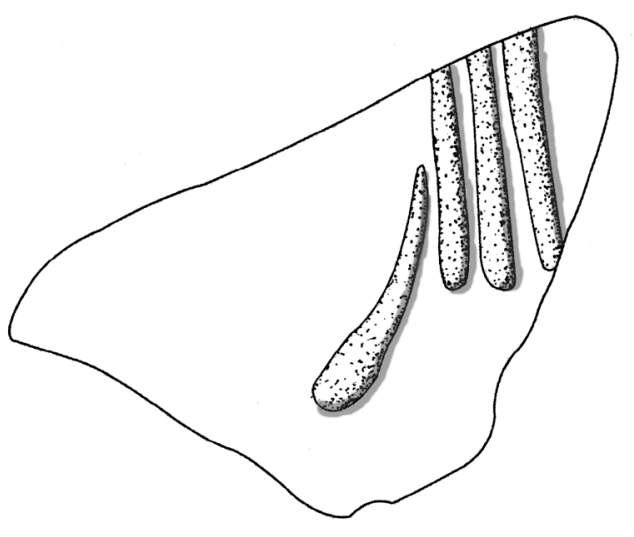

a

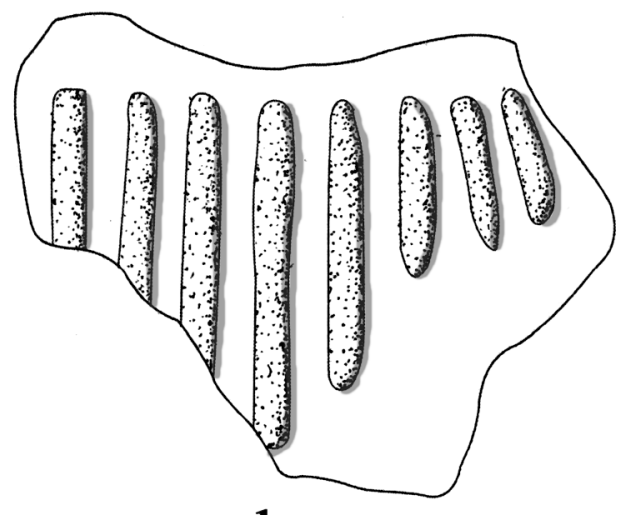

b

Figure 7. Decorative elements on Harleton Appliqued body sherds from the Avery Rasurer site (41HP10).

The two fine ware sherds in the collections from the Avery Rasurer site have a red slip on both vessel surfaces (see Table 8). These may be from Sanders Slipped vessels - suggesting use of the site during the Middle Caddo period-but it is more likely they are from red-slipped Titus phase vessels, or the nonengraved portions of red-slipped carinated bowls. 


\section{Tom Cannon Farm (41HP11)}

In 1933, J. B. Scoggin found a few ceramic vessels in an eroded ravine near an ancestral Caddo settlement. Scoggins donated a surface collection to UT in June 1935. The surface collection has 36 ceramic vessel sherds from plain ware $(n=33)$, utility ware $(n=2)$, and fine ware $(n=1)$ vessels. More than 91 percent of the sherds are from grog-tempered vessels, and the remainder (8.3 percent) are from grogbone-tempered vessels.

The decorated utility ware sherds include a body sherd with a straight appliqued ridge and a body sherd with fingernail punctated rows (possibly from a Monkstown Fingernail Impressed vessel, see Suhm and Jelks 1962:Plate 55). The grog-tempered fine ware body sherd in the collection has a single curvilinear engraved line.

\section{Summary and Conclusions}

Analysis of the ancestral Caddo ceramic vessel sherds $(n=464)$ and vessels $(n=5$, see Perttula and Walters 2016)) recovered by UT archaeologists in 1931 and 1934 from five different sites in Hopkins County in the White Oak Creek basin in East Texas indicate that the sites were occupied by Caddo groups either between ca. A.D. 1200-1400 (at the E. B. Minter, R. H. Taylor, Hilman Hathcoat, and Tom Cannon sites) or after ca. A.D. 1400 (at the E. B. Minter, R. H. Taylor, and Avery Rasurer sites). The Middle Caddo period occupations have Sanders Engraved, Canton Incised, and Sanders Slipped sherds, which are found in Sanders phase sites in the Red River, Sulphur River, and Sabine River basins in East Texas. The post-A.D. 1400 ceramics in the White Oak Creek basin sites, including Ripley Engraved, Harleton Appliqued, La Rue Neck Banded, and Maydelle Incised, are related to Titus phase ceramic assemblages in Sulphur River (Perttula 2016) and Big Cypress Creek (see Perttula 2012) basin settlements and cemeteries.

\section{Acknowledgments}

Thanks to Lauren Bussiere of TARL for facilitating access to the collections from these Hopkins County sites. Drew Sitters prepared Figure 5, while Lance Trask prepared the remainder of the figures for this article.

\section{References Cited}

Jackson, A. T.

1931 Excavation of a Burial Site on E. B. Minter Farm, 6 miles N.W. of Weaver, Hopkins County, Texas. MS on file, Texas Archeological Research Laboratory, The University of Texas at Austin.

1934 R. H. Taylor Farm on Crosstimber Creek and Colquitt Branch 1 Mile Northeast of Dike, Hopkins County, Texas, Tested July 19, 1934 to July 20, 1934. MS on file, Texas Archeological Research Laboratory, The University of Texas at Austin.

Perttula, T. K.

2012 The Character of Fifteenth- to Seventeenth-Century Caddo Communities in the Big Cypress Creek Basin of Northeast Texas. In The Archaeology of the Caddo, edited by T. K. Perttula and C. P. Walker, pp. 363-410. University of Nebraska Press, Lincoln.

2016 The W. A. Ford Site (41Tt2), Titus County, Texas. Journal of Northeast Texas Archaeology 60:1-52. 
Perttula, T. K. and M. Walters

2016 Caddo Ceramic Vessels from the E. B. Minter (41HP2) and Roger Attaway (41HP15) Sites in Hopkins County, Texas. Journal of Northeast Texas Archaeology 63:63-73.

Perttula, T. K., M. Walters, and B. Nelson

2016 Caddo Ceramic Vessels from the T. M. Sanders Site (41LR2) on the Red River in Lamar County, Texas. Special Publication No. 41. Friends of Northeast Texas Archaeology, Austin and Pittsburg.

Suhm, D. A. and E. B. Jelks (editors)

1962 Handbook of Texas Archeology: Type Descriptions. Special Publication No. 1, Texas Archeological Society, and Bulletin No. 4, Texas Memorial Museum, Austin. 